\title{
Comparison of Nanopowdered and Powdered Peanut Sprout-Added Yogurt on its Physicochemical and Sensory Properties during Storage
}

\author{
Yu-Jin Ahn, Palanivel Ganesan, and Hae-Soo Kwak* \\ Department of Food Science and Technology, Sejong University, Seoul 143-747, Korea
}

\begin{abstract}
This study was conducted to compare the physicochemical and sensory properties of yogurt containing nanopowdered peanut sprouts (NPPS) and powdered peanut sprouts (PPS) at different concentrations $(0.05-0.20 \%$, w/v) during storage at $4^{\circ} \mathrm{C}$ for $16 \mathrm{~d}$. The $\mathrm{pH}$ values of NPPS $(0.05-0.20 \%$, w/v)-added yogurt were lower than those of PPS-added yogurt. The antiradical scavenging activity and LAB counts were significantly higher in NPPS-added yogurt than in PPS-added yogurt during the storage period of $16 \mathrm{~d}(p<0.05)$. Higher concentrations $(0.15$, and $0.20 \%)$ NPPS-added yogurt showed greater antiradical scavenging activity. The LAB counts were ranged from $9.00 \times 10^{8}$ to $1.10 \times 10^{9}$ and $1.30 \times 10^{9}$ to $9.10 \times 10^{8} \mathrm{CFU} / \mathrm{mL}$ in $0.05 \%$ and $0.20 \%$ NPPS-added yogurts, respectively. In sensory testing, 0.05 and $0.10 \%$ NPPS-added yogurt showed similar results to the control in whey-off, grainy texture, and overall acceptability. Yellowness and astringent scores increased with increasing addition of NPPS or PPS to the yogurt irrespective of its storage times. Peanut and beany flavors were lower during the storage for 0.05 and $0.10 \%$ NPPS-added yogurt. Based on the data obtained from the present study, it was concluded that 0.05 and $0.10 \%, \mathrm{w} / \mathrm{v}$ of NPPS could be used to produce NPPS-added yogurt without significant adverse effects on the physicochemical and sensory properties, but with an enhanced functional value added to the yogurt.
\end{abstract}

Key words: yogurt, nanopowdered peanut sprout, antioxidant activity, sensory properties

\section{Introduction}

Yogurt serves as a functional healthy food due to high bioavailability of proteins, fats, calcium, and minerals. Further during fermentation of yogurt various bioactive compounds can be derived which includes range of peptides (Gobbetti et al., 2004). In addition to the plain yogurt, some flavored yogurt is also produced, either by the addition of synthetic flavor or by the natural ingredients, such as fruit juices of apple, strawberry, raspberry etc which has the higher sources of anthocyanins. The addition of the fruit juice or dried fruit increases the bioactivity of the functional yogurt through the supplement of the polyphenols. Polyphenols are generally rich in plant food which shows higher antioxidant and antiradical scavenging activity. Consumption of these plant polyphenols shows various health enhancing functions in humans (Servili et al., 2009). However, the content of polyphenol varies with the food sources.

*Corresponding author: Hae-Soo Kwak, Department of Food Science and Technology, Sejong University, Seoul 143-747, Korea. Tel: 82-2-3408-3226; Fax: 82-2-3408-4319, E-mail: kwakhs@sejong.ac.kr
Resveratrol, a naturally occurring polyphenols, showed various health benefits in human and animal studies, which includes antinflammatory, anticancer, antiarthritic effects and antidiabetic (Sharma et al., 2006). Resveratrol is also rich in various plant foods which include grapes and red wines ( 0.03 to $7.17 \mu \mathrm{g} / \mathrm{g})$, peanuts $(0.01-1.79 \mu \mathrm{g} /$ g) and cranberry juice $(0.24 \mu \mathrm{g} / \mathrm{g})$ (Kang et al., 2010; Wang et al., 2002;). However, peanut sprouts are rich in resveratrol with an average content of $110.05 \mu \mathrm{g} / \mathrm{g}$ (Kang et al., 2010). Futher there was no report regarding the addition of powdered peanut sprout rich in resveratrol into yogurt and development of functional yogurt.

Functional properties and stability of various foods can be enhanced by using the emerging novel technique such as nanosizing (Park et al., 2007). Nanosized ascorbatesolubilized chitosan increases the bioactivity in yogurt and milk (Seo et al., 2009; Seo et al., 2011). Further nanosize calcium supplementation in milk enhances the bone calcium metabolism in ovarirectomized rats (Park et al., 2007). However, there are no informations on developing the functional yogurt which incorporates the nanopowdered peanut sprout. Due to the increase concern of health among consumers and to meet the demand of functional yogurt, a new functional yogurt should be developed 
using the appropriate functional ingredients, such as nanaopowdered peanut sprout. Therefore, the objective of the present study was to compare the physicochemical and sensory properties of the yogurt added with nanopowdered and powdered peanut sprouts during storage.

\section{Materials and Methods}

\section{Materials}

Commercial peanut sprout was offered from Jangsuche. Co., Ltd. (Seoul, Korea). Peanut sprouts were ground to nanopowdered peanut sprout (NPPS) and regular powdered peanut sprouts (PPS) by the dry milling method at room temperature in Apexcel Co. (Pohang, Korea). Market milk (3.8\% milk fat) was purchased from Seoul Dairy Co-op. (Seoul, Korea). All chemicals were purchased from Sigma Chemical Co. (St. Louis, USA), and all solvents were of chromatographic grade.

\section{Manufacture of NPPS-Enriched yogurt}

Milk containing 3.6\% fat and $13.4 \%$ total solids was added with $3.7 \%(\mathrm{w} / \mathrm{v})$ skim milk powder and different concentrations $(0.05,0.10,0.15$, and $0.20 \%)$ of NPPS with the average particle size of $300-350 \mathrm{~nm}$ or PPS with the average particle size of 50 to $150 \mu \mathrm{m}$ in Figs. 1 and 2 were blended with Lab-blender (MS3040, MTops Misung, Seoul, Korea) at $400 \mathrm{rpm}$ for $5 \mathrm{~min}$. Each batch was made with $10 \mathrm{~L}$ of milk ( $2 \mathrm{~L}$ per treatment) at lab-scale level. The milk added with NPPS or PPS was heated at $90^{\circ} \mathrm{C}$ for $10 \mathrm{~min}$ in water bath and cooled to approxi-

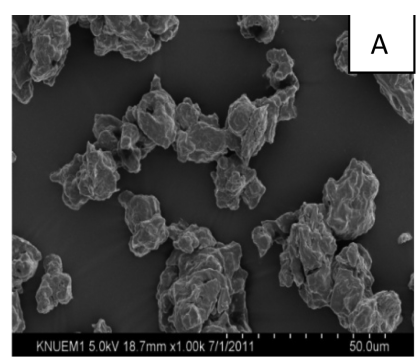

Nanopowdered peanut sprout

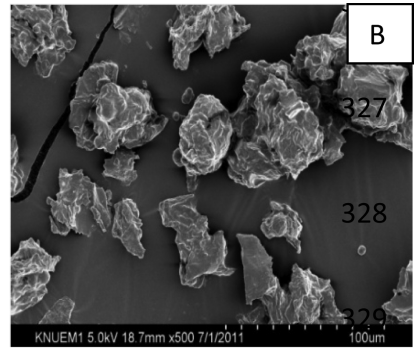

Powdered peanut sprout
Fig. 1. Scanning electron microscope image of nanopowdered and powdered peanut sprouts.

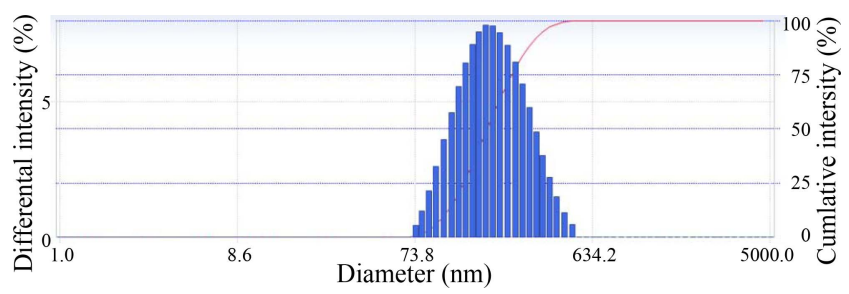

Fig. 2. Particle size analysis of nanopowdered peanut sprout. mately $42^{\circ} \mathrm{C}$. A $0.02 \%$ commercial starter culture (Chr. Hansen, Pty. Ltd, Bayswater, Australia) in freeze-dried direct-to-vat set form containing L. bulgaricus, S. thermophilus, and B. bifidum was added and fermented at $43^{\circ} \mathrm{C}$ for $6 \mathrm{~h}$ approximately the $\mathrm{pH}$ reached 4.5. After fermentation, each yogurt sample was stored for $0,4,8,12$ and 16 $\mathrm{d}$ at $4^{\circ} \mathrm{C}$ in a refrigerator to evaluate the physicochemical and sensory properties. Each batch of yogurt making was done in triplicate.

\section{pH}

The $\mathrm{pH}$ values of the NPPS or PPS enriched yogurt samples were measured using a glass electrode $\mathrm{pH}$ meter (Orion 900A, USA).

\section{Viscosity}

The viscosity of yogurt samples $(100 \mathrm{~mL})$ was measured after mixing of the sample for $5 \mathrm{~min}$ at room temperature using a Brookfield viscometer (Model LVDV I+, Version 3.0, USA) with a spindle no 2 at $60 \mathrm{rpm}$. All samples were measured in triplicate.

\section{Microbial Analysis}

MRS plate count agar (Difco Laboratories, Detroit, MI, USA) was used for lactic acid bacteria counting. One milliliter of yogurt samples was diluted with $9 \mathrm{~mL}$ of sterile peptone and water diluents. Subsequent dilutions of each sample were plated in triplicate and incubated at $37^{\circ} \mathrm{C}$ for $48 \mathrm{~h}$.

\section{DPPH Radical Scavenging Activity}

The free radical scavenging activities of NPPS- or PPSadded yogurt were measured by the 2,2-diphenyl-1-picryl-hydrazil (DPPH) method proposed by Brand-Williams et al. (1995). Briefly, $0.1 \mathrm{mM}$ solution of DPPH in ethanol was prepared and $1.0 \mathrm{~mL}$ of this solution was added to $0.5 \mathrm{~mL}$ of samples in different concentrations. After $20 \mathrm{~min}$, the absorbance was measured at $525 \mathrm{~nm}$. The DPPH radical scavenging activity was calculated according to the following equation:

DPPH radical scavenging activity (\%)

$=\left[\left(\mathrm{A}_{0}-\mathrm{A}_{1}\right) / \mathrm{A}_{0}\right] 100$

Where $A_{0}$ was the absorbance of the control and $A_{1}$ the absorbance in the presence of the test compound.

\section{Color Measurement}

Color values of yogurt sample added with NPPS or PPS were measured using a Hunter colorimeter (Minolta 
CT-310, Tokyo, Japan) after calibrating its original value with a standard plate $(X=97.83, Y=81.58, Z=91.51)$. Measured $L^{*}, a^{*}$ and $b^{*}$ values were used as indicators of lightness, redness and yellowness, respectively.

\section{Sensory Analysis}

The sensory evaluation was performed by 8 trained panelists, who were the graduate students (4 males and 4 females) in the Dairy Products Laboratory (Food Science and Technology Department, Sejong University, Seoul, Korea), aged 25 to $33 \mathrm{yr}$, and familiar with yogurt consumption. Panelists were trained in 2 sessions using a 7point scale, where 1 represented very weak peanut flavor, yellow color, and taste, and 7 represented very strong peanut flavor, yellow color, and taste. Reference samples prepared at the level of 1, 5, and 9\% NPPS- or PPS-added yogurt were kept in a closed cup for $0,4,8,12$, and $16 \mathrm{~d}$. To test the flavor of samples, the panelists were asked to open the closed cup and sniff the headspace above the samples. The samples were then scored.

\section{Statistical Analysis}

All statistical analyses were performed using SAS version 9.0 (SAS Institute, 2002). An ANOVA was performed using the general linear models procedure to determine significant differences among the samples. Means were compared by using Duncan's multiple range test $(p<0.05)$.

\section{Results and Discussion}

\section{pH}

The changes in $\mathrm{pH}$ values of yogurt samples added with various concentrations $(0.05,0.10,0.15$, and $0.20 \%)$ of NPPS and PPS during $16 \mathrm{~d}$ of storage at $4^{\circ} \mathrm{C}$ are shown

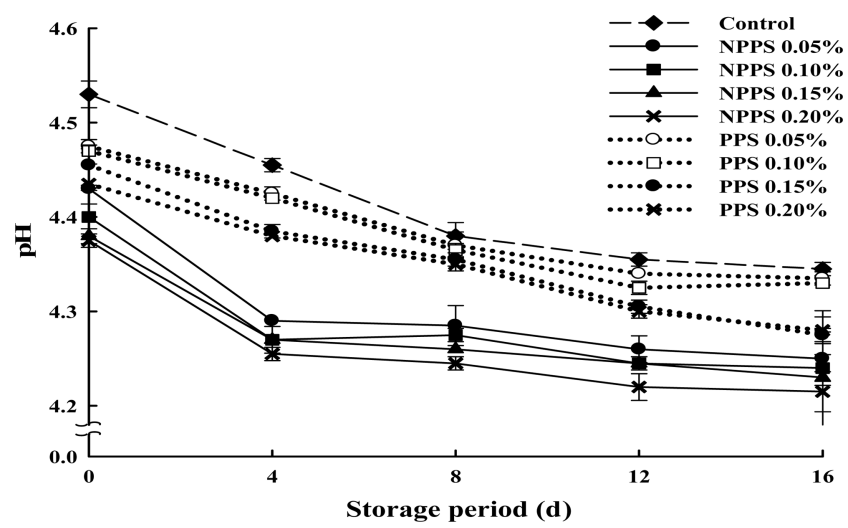

Fig. 3. Changes of $\mathrm{pH}$ in nanopowdered peanut sprout- and powdered peanut sprout-added yogurts stored at $4^{\circ} \mathrm{C}$ for $16 \mathrm{~d}$. NPPS: nanopowdered peanut sprout; PPS: powdered peanut sprout in Fig. 3. The $\mathrm{pH}$ values of the yogurt samples were ranged from 4.0 to 4.4 as a reflective of the fresh state (Seo et al., 2009; Sahan et al., 2008). At 0 d of storage $\mathrm{pH}$ value of PPS-added yogurt and control were slightly higher, whereas NPPS-added yogurt samples were in the normal range. Increasing the storage period from 0 to $16 \mathrm{~d}$ significantly decreased the $\mathrm{pH}$ values 4.45 to 4.25 , indicating that the yogurt quality was acceptable during $16 \mathrm{~d}$ storage $(p<0.05)$. Dramatic decrease of $\mathrm{pH}$ was observed during $4 \mathrm{~d}$ of storage irrespective of concentrations $(0.05,0.10,0.15$, and $0.20 \%$ ) of NPPS addition. Lower $\mathrm{pH}$ was most likely due to the higher production of lactic acid during the storage period of $16 \mathrm{~d}$ (Abodjo Kakou et al., 2010; Kim et al., 2011). Reducing sugars in milk can be hydrolyzed by the enzymes of LAB, which can be further metabolized into lactic acid (Kim et al., 2011). Higher the concentrations of PPS or NPPS addition in yogurt greater the decreased in $\mathrm{pH}$ value. Seo et al. (2009) also observed that addition of nanopowdered chitosan decreased the $\mathrm{pH}$ values during the storage period of $16 \mathrm{~d}$. However, $\mathrm{pH}$ was significantly lower in NPPS- than in PPS-added yogurt, irrespective of its concentrations and its storage time $(p<0.05)$.

\section{Changes in Viscosity}

The viscosity value of yogurt samples added with various concentrations $(0.05,0.10,0.15$, and $0.20 \%)$ of NPPS and PPS during $16 \mathrm{~d}$ of storage at $4^{\circ} \mathrm{C}$ are shown in Fig. 4. Increasing the concentration $(0.05,0.10,0.15$, and $0.20 \%$ ) of PPS and NPPS addition greatly increased the viscosity values at $0 \mathrm{~d}$ of storage. However, viscosity of NPPS addition was significantly higher than the PPS ad-

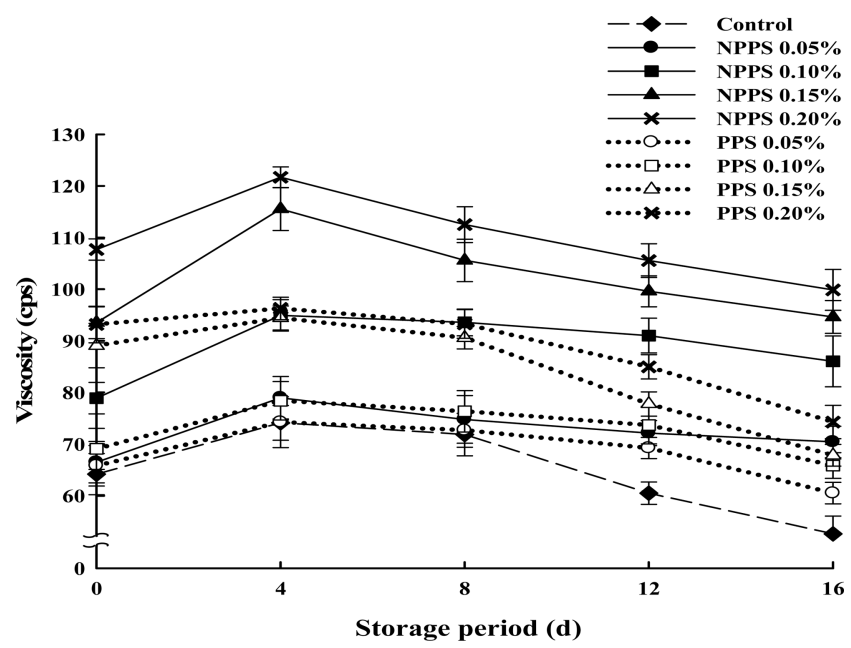

Fig. 4. Changes of viscosity in nanopowdered peanut sproutand powdered peanut sprout-added yogurts stored at $4^{\circ} \mathrm{C}$ for $16 \mathrm{~d}$. NPPS: nanopowdered peanut sprout; PPS: powdered peanut sprout 
dition to the yogurt, irrespective of its concentrations used $(p<0.05)$. It was highly correlated with the $\mathrm{pH}$ which was found greater decreased in the $\mathrm{pH}$ of NPPS-added yogurt (Fig. 3). The increasing value of viscosity was most likely due to the rearrangement of the protein molecules (Isleten and Karagul Yuccer, 2006; Sahan et al., 2008). Further the viscosity values were greatly increased during $4 \mathrm{~d}$ and gradually decreased during the storage period of $16 \mathrm{~d}$, irrespective of the type and concentrations of peanut sprout added to the yogurt. It was highly correlated with the $\mathrm{pH}$ of NPPS- and PPS-added yogurt. Increasing the viscosity was most likely due to the production of viscous exopolysaccharides along with the lactic acid by lactic acid bacteria during the storage (Vijayendra et al., 2008). However, the lower concentrations $(0.05$ and $0.10 \%)$ of NPPSadded yogurt samples showed similar viscosity values of control during storage of $16 \mathrm{~d}$.

\section{Changes in DPPH}

The changes in DPPH of NPPS- and PPS-added yogurts during storage at $4^{\circ} \mathrm{C}$ for $16 \mathrm{~d}$ are shown in Fig. 5. The radical scavenging activities are normally used to measure the capacity of antioxidant activity in various plant and animal foods (Kang et al., 2010). DPPH radical scavenging activity was found to be lower in the control (without addition of NPPS or PPS). However, increasing the concentrations of NPPS or PPS $(0.05,0.10,0.15$, and $0.20 \%)$ significantly increased the DPPH radical scavenging activity in NPPS- or PPS-added yogurt $(p<0.05)$. NPPS and PPS are rich in resveratrol and other plant polyphenolics which has greater antioxidant activity (Kang et

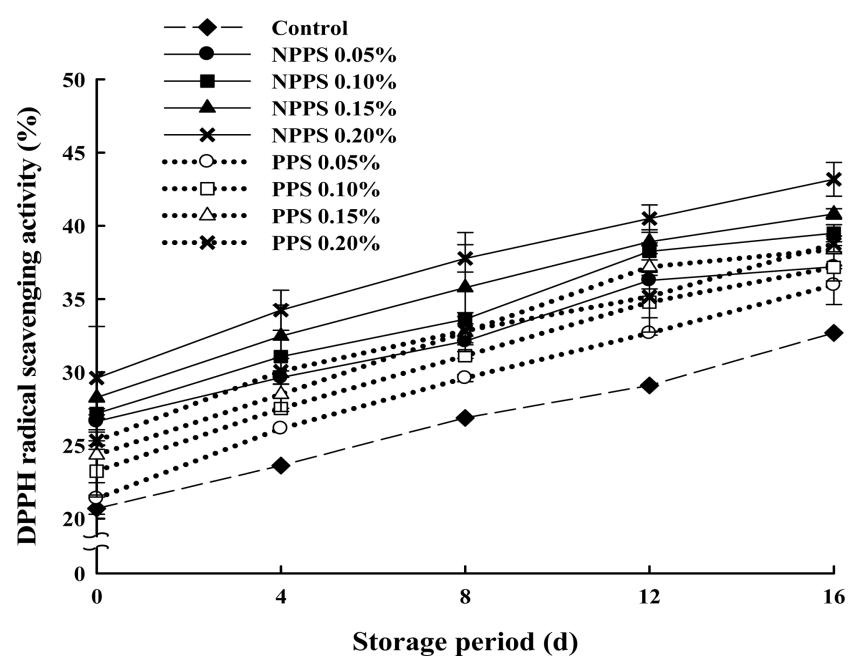

Fig. 5. Changes of DPPH radical scavenging in nanopowdered peanut sprout- and powdered peanut sproutadded yogurts stored at $4^{\circ} \mathrm{C}$ for $16 \mathrm{~d}$. NPPS: nanopowdered peanut sprout; PPS: powdered peanut sprout al., 2010). However, the DPPH radical scavenging activity was found to be greater in NPPS than PPS irrespective of its concentrations added to yogurt. NPPS provides greater surface area and more exposure of functional group, thus it leads to greater antiradical scavenging activity (Park et al., 2007). Higher the concentration of NPPSadded yogurt (0.15, and $0.20 \%$ ) was found to be higher radical scavenging activity during the storage of yogurt.

\section{Changes in $\mathrm{LAB}$ counts}

The changes in L. bulgaricus, S. thermophilus, and B. bifidum of NPPS- and PPS-added yogurt during storage at $4^{\circ} \mathrm{C}$ for $16 \mathrm{~d}$ are shown in Table 1 . The mean microbial count increased significantly at $4 \mathrm{~d}(p<0.05)$ and gradually decreased during the storage period irrespective of its concentrations $(0.05,0.10,0.15$, and $0.20 \%)$ and types of peanut sprout (PPS or NPPS) added to the yogurt. However, NPPS showed greater value of LAB than PPSadded yogurt and control. This was highly correlated with $\mathrm{pH}$ which showed greater decreased in $\mathrm{pH}$ of NPPSadded yogurt during $16 \mathrm{~d}$ storage (Fig. 3). The increase in the storage period of $16 \mathrm{~d}$ showed the decrease in the LAB counts in NPPS- and PPS-added yogurt. However, the decrease was significantly higher in PPS- than NPPSadded yogurt. This was most likely due to the nanogrinding of peanut sprout which provides greater surface area for the microbial growth than the regular powdered peanut sprout.

\section{Color}

The changes in color of NPPS- and PPS-added yogurt samples stored at $4^{\circ} \mathrm{C}$ for $16 \mathrm{~d}$ are presented in Table 2 . The $\mathrm{L}^{*}$ values of the yogurt added with different concentrations $(0.05,0.10,0.15$, and $0.20 \%)$ of NPPS or PPS were not significantly differ at increasing storage of $16 \mathrm{~d}$ $(p>0.05)$. The supplementation of the NPPS or PPS in yogurt samples would not influence the consumer appeal over the extended storage of $16 \mathrm{~d}$. Increasing the concentration of NPPS or PPS addition in yogurt were not increased the $\mathrm{a}^{*}$ value at $0 \mathrm{~d}$. However, increasing the storage time to $16 \mathrm{~d}$ was significantly increased the $\mathrm{a}^{*}$ value for NPPS- and PPS-added yogurt $(p<0.05)$. Further $a^{*}$ value was found to be higher in PPS-added yogurt than in NPPS. Shirai et al. (1992) also observed that yogurt synersis lead to decrease in the $\mathrm{a}^{*}$ value of yogurt due to the release of whey which has very important green component. Increasing the concentrations of NPPS or PPS addition at $0 \mathrm{~d}$ markedly increased the $\mathrm{b}^{*}$ values, most likely due to the light yellow color of NPPS or PPS. Similarly 
Table 1. The viable cells ${ }^{1)}$ of nanopowdered peanut sprout- and powdered peanut sprout-added yogurts stored at $4^{\circ} \mathrm{C}$ for $16 \mathrm{~d}$

\begin{tabular}{|c|c|c|c|c|c|c|}
\hline \multirow{2}{*}{\multicolumn{2}{|c|}{$\begin{array}{l}\text { Concentration of } \\
(\%, w / v) \text { sample }\end{array}$}} & \multicolumn{5}{|c|}{ Storage period (d) } \\
\hline & & 0 & 4 & 8 & 12 & 16 \\
\hline \multicolumn{2}{|c|}{ Control } & $7.45 \times 10^{8 \mathrm{cAB} 2)}$ & $9.15 \times 10^{8 \mathrm{cA}}$ & $9.40 \times 10^{8 \mathrm{bA}}$ & $6.45 \times 10^{8 \mathrm{cBC}}$ & $4.50 \times 10^{8 \mathrm{cC}}$ \\
\hline \multirow{4}{*}{ NPPS $^{3)}$} & 0.05 & $9.00 \times 10^{8 \mathrm{bcB}}$ & $1.63 \times 10^{9 \mathrm{abA}}$ & $1.20 \times 10^{9 \mathrm{aB}}$ & $1.17 \times 10^{9 \mathrm{aB}}$ & $1.10 \times 10^{9 \mathrm{aB}}$ \\
\hline & 0.10 & $9.35 \times 10^{8 \mathrm{bcC}}$ & $1.84 \times 10^{9 \mathrm{aA}}$ & $9.00 \times 10^{8 \mathrm{bCD}}$ & $1.14 \times 10^{9 \mathrm{aB}}$ & $7.20 \times 10^{8 \mathrm{bcD}}$ \\
\hline & 0.15 & $1.06 \times 10^{9 \mathrm{abA}}$ & $1.24 \times 10^{9 \mathrm{bcA}}$ & $1.20 \times 10^{9 \mathrm{aA}}$ & $1.10 \times 10^{9 \mathrm{aA}}$ & $9.00 \times 10^{8 \mathrm{abA}}$ \\
\hline & 0.20 & $1.30 \times 10^{9 \mathrm{aAB}}$ & $1.59 \times 10^{9} \mathrm{abA}$ & $8.20 \times 10^{8 \mathrm{bC}}$ & $8.00 \times 10^{8 \mathrm{bcC}}$ & $9.10 \times 10^{8}$ abBC \\
\hline \multirow{4}{*}{$\mathrm{PPS}^{4)}$} & 0.05 & $7.65 \times 10^{8 \mathrm{bcAB}}$ & $8.00 \times 10^{8 \mathrm{cAB}}$ & $9.05 \times 10^{8 \mathrm{bA}}$ & $6.95 \times 10^{8 \mathrm{bcAB}}$ & $5.00 \times 10^{8 \mathrm{cB}}$ \\
\hline & 0.10 & $7.60 \times 10^{8 \mathrm{bcA}}$ & $8.20 \times 10^{8 \mathrm{cA}}$ & $8.85 \times 10^{8 \mathrm{bA}}$ & $5.75 \times 10^{8 \mathrm{cA}}$ & $5.60 \times 10^{8 \mathrm{bcA}}$ \\
\hline & 0.15 & $8.45 \times 10^{8 \mathrm{bcA}}$ & $7.50 \times 10^{8 \mathrm{cA}}$ & $7.90 \times 10^{8 \mathrm{bA}}$ & $9.65 \times 10^{8 \mathrm{abA}}$ & $7.50 \times 10^{8 \mathrm{bcA}}$ \\
\hline & 0.20 & $9.10 \times 10^{8 \mathrm{bcA}}$ & $8.00 \times 10^{8 \mathrm{cA}}$ & $8.35 \times 10^{8 \mathrm{bA}}$ & $6.30 \times 10^{8 \mathrm{cA}}$ & $7.05 \times 10^{8 \mathrm{bcA}}$ \\
\hline
\end{tabular}

${ }^{15}$ S. thermophilus, L. bulgaricus, and B. bifidium mixed starter culture yogurt

${ }^{2)}$ Values with different superscript in a row (A-D) and column (a-c) are significant at $p<0.05$ by Duncan's multiple range test.

${ }^{3)}$ NPPS, Nanopowdered peanut sprout

${ }^{4)} \mathrm{PPS}$, Powdered peanut sprout

Table 2. Changes in color of nanopowdered peanut sprout- and powdered peanut sprout-added yogurts stored at $4^{\circ} \mathrm{C}$ for $16 \mathrm{~d}$

\begin{tabular}{|c|c|c|c|c|c|c|c|}
\hline \multirow{2}{*}{\multicolumn{3}{|c|}{$\begin{array}{c}\text { Concentrations }(\%, \mathrm{w} / \mathrm{v}) \\
\text { of sample }\end{array}$}} & \multicolumn{5}{|c|}{ Storage period (d) } \\
\hline & & & 0 & 4 & 8 & 12 & 16 \\
\hline \multirow{9}{*}{$\begin{array}{c}\mathrm{L}^{*} \\
\text { (light } \\
\text {-ness) }\end{array}$} & \multicolumn{2}{|c|}{ control } & $86.96 \pm 0.31^{1 \mathrm{labA2} 2}$ & $87.04 \pm 0.33^{\mathrm{aA}}$ & $87.00 \pm 0.23^{\mathrm{bA}}$ & $87.12 \pm 0.20^{\mathrm{aA}}$ & $87.01 \pm 0.26^{\mathrm{bA}}$ \\
\hline & \multirow{4}{*}{$\mathrm{NPPS}^{3)}$} & 0.05 & $86.70 \pm 0.44 \mathrm{bB}$ & $87.09 \pm 0.30^{\mathrm{aA}}$ & $87.00 \pm 0.20^{\mathrm{bAB}}$ & $87.10 \pm 0.36^{\mathrm{aA}}$ & $87.02 \pm 0.34^{\mathrm{abA}}$ \\
\hline & & 0.1 & $87.07 \pm 0.47^{\mathrm{aA}}$ & $87.02 \pm 0.37^{\mathrm{aA}}$ & $87.36 \pm 0.30^{\mathrm{aA}}$ & $87.14 \pm 0.25^{\mathrm{aA}}$ & $87.13 \pm 0.32^{\mathrm{abA}}$ \\
\hline & & 0.15 & $86.96 \pm 0.29^{\mathrm{abA}}$ & $87.06 \pm 0.18^{\mathrm{aA}}$ & $87.19 \pm 0.29^{\mathrm{abA}}$ & $87.07 \pm 0.22^{\mathrm{aA}}$ & $87.07 \pm 0.35^{\mathrm{abA}}$ \\
\hline & & 0.2 & $86.91 \pm 0.25^{\mathrm{abB}}$ & $87.04 \pm 0.22^{\mathrm{aAB}}$ & $87.21 \pm 0.34^{\mathrm{abA}}$ & $87.04 \pm 0.22^{\mathrm{aAB}}$ & $87.09 \pm 0.23^{\mathrm{abAB}}$ \\
\hline & \multirow{4}{*}{$\mathrm{PPS}^{4)}$} & 0.05 & $87.12 \pm 0.33^{\mathrm{aA}}$ & $87.19 \pm 0.34^{\mathrm{aA}}$ & $87.07 \pm 0.22^{\mathrm{bA}}$ & $87.10 \pm 0.21^{\mathrm{aA}}$ & $87.10 \pm 0.25^{\mathrm{abA}}$ \\
\hline & & 0.1 & $87.09 \pm 0.35^{\mathrm{aA}}$ & $87.09 \pm 0.17^{\mathrm{aA}}$ & $87.11 \pm 0.20^{\mathrm{bA}}$ & $87.14 \pm 0.35^{\mathrm{aA}}$ & $87.12 \pm 0.22^{\mathrm{abA}}$ \\
\hline & & 0.15 & $87.02 \pm 0.12^{\mathrm{abB}}$ & $87.01 \pm 0.24^{\mathrm{aB}}$ & $87.04 \pm 0.23^{\mathrm{bB}}$ & $87.10 \pm 0.21^{\mathrm{aAB}}$ & $87.27 \pm 0.12^{\mathrm{abA}}$ \\
\hline & & 0.2 & $86.94 \pm 0.22^{\mathrm{abB}}$ & $86.99 \pm 0.21^{\mathrm{aB}}$ & $87.03 \pm 0.20^{\mathrm{bB}}$ & $87.26 \pm 0.31^{\mathrm{aA}}$ & $87.28 \pm 0.11^{\mathrm{aA}}$ \\
\hline \multirow{9}{*}{$\begin{array}{c}\mathrm{a}^{*} \\
\text { (red } \\
\text {-ness) }\end{array}$} & \multicolumn{2}{|c|}{ control } & $2.34 \pm 0.15^{\mathrm{bB}}$ & $2.24 \pm 0.08^{\mathrm{cC}}$ & $2.20 \pm 0.07^{\mathrm{dC}}$ & $2.23 \pm 0.12^{\mathrm{cC}}$ & $2.54 \pm 0.08^{\mathrm{aA}}$ \\
\hline & \multirow{4}{*}{ NPPS $^{3)}$} & 0.05 & $2.30 \pm 0.19^{\mathrm{bB}}$ & $2.26 \pm 0.18^{\mathrm{cB}}$ & $2.27 \pm 0.05^{\mathrm{dB}}$ & $2.25 \pm 0.12^{\mathrm{cB}}$ & $2.66 \pm 0.17^{\mathrm{aA}}$ \\
\hline & & 0.1 & $2.23 \pm 0.20^{\mathrm{bB}}$ & $2.29 \pm 0.15^{\mathrm{cB}}$ & $2.23 \pm 0.11^{\mathrm{dB}}$ & $2.25 \pm 0.10^{\mathrm{cB}}$ & $2.63 \pm 0.37^{\mathrm{aA}}$ \\
\hline & & 0.15 & $2.28 \pm 0.04^{\mathrm{bB}}$ & $2.32 \pm 0.04^{\mathrm{cB}}$ & $2.28 \pm 0.08^{\mathrm{dB}}$ & $2.20 \pm 0.10^{\mathrm{cC}}$ & $2.58 \pm 0.10^{\mathrm{aA}}$ \\
\hline & & 0.2 & $2.24 \pm 0.10^{\mathrm{bC}}$ & $2.35 \pm 0.06^{\mathrm{cB}}$ & $2.24 \pm 0.11^{\mathrm{dC}}$ & $2.23 \pm 0.09^{\mathrm{cC}}$ & $2.54 \pm 0.08^{\mathrm{aA}}$ \\
\hline & \multirow{4}{*}{$\mathrm{PPS}^{4)}$} & 0.05 & $2.51 \pm 0.18^{\mathrm{aAB}}$ & $2.49 \pm 0.09^{\mathrm{bAB}}$ & $2.41 \pm 0.08^{\mathrm{cB}}$ & $2.42 \pm 0.12^{\mathrm{bAB}}$ & $2.54 \pm 0.11^{\mathrm{aA}}$ \\
\hline & & 0.1 & $2.58 \pm 0.10^{\mathrm{aAB}}$ & $2.63 \pm 0.10^{\mathrm{aA}}$ & $2.51 \pm 0.12^{\mathrm{bB}}$ & $2.56 \pm 0.19^{\mathrm{aAB}}$ & $2.55 \pm 0.07^{\mathrm{aAB}}$ \\
\hline & & 0.15 & $2.56 \pm 0.04^{\mathrm{aCD}}$ & $2.66 \pm 0.12^{\mathrm{aAB}}$ & $2.70 \pm 0.08^{\mathrm{aA}}$ & $2.60 \pm 0.10^{\mathrm{aBC}}$ & $2.51 \pm 0.06^{\mathrm{aD}}$ \\
\hline & & 0.2 & $2.57 \pm 0.04^{\mathrm{aBC}}$ & $2.69 \pm 0.07^{\mathrm{aA}}$ & $2.71 \pm 0.07^{\mathrm{aA}}$ & $2.64 \pm 0.16^{\mathrm{aAB}}$ & $2.51 \pm 0.08^{\mathrm{aC}}$ \\
\hline \multirow{9}{*}{$\begin{array}{c}b^{*} \\
\text { (yellow } \\
\text {-ness) }\end{array}$} & \multicolumn{2}{|c|}{ control } & $4.27 \pm 0.38^{\mathrm{dA}}$ & $4.21 \pm 0.20^{\mathrm{dA}}$ & $4.25 \pm 0.15^{\mathrm{eA}}$ & $4.15 \pm 0.14^{\mathrm{cA}}$ & $4.24 \pm 0.20^{\mathrm{eA}}$ \\
\hline & \multirow{4}{*}{$\mathrm{NPPS}^{3)}$} & 0.05 & $4.30 \pm 0.53^{\mathrm{dA}}$ & $4.29 \pm 0.57^{\mathrm{dA}}$ & $4.29 \pm 0.37^{\mathrm{eA}}$ & $4.11 \pm 0.45^{\mathrm{cA}}$ & $4.40 \pm 0.26^{\mathrm{edA}}$ \\
\hline & & 0.1 & $4.61 \pm 0.55^{\mathrm{dcA}}$ & $4.53 \pm 0.53^{\mathrm{dA}}$ & $4.58 \pm 0.44^{\mathrm{eA}}$ & $4.31 \pm 0.41^{\mathrm{bcA}}$ & $4.65 \pm 0.24^{\mathrm{dA}}$ \\
\hline & & 0.15 & $4.96 \pm 0.14^{\mathrm{bcB}}$ & $5.16 \pm 0.26^{\mathrm{bcAB}}$ & $5.23 \pm 0.30^{\mathrm{dcA}}$ & $4.38 \pm 0.32^{\mathrm{bcC}}$ & $5.18 \pm 0.22^{\mathrm{cAB}}$ \\
\hline & & 0.2 & $5.28 \pm 0.44^{\mathrm{abA}}$ & $5.37 \pm 0.31^{\mathrm{bA}}$ & $5.40 \pm 0.46^{\mathrm{bcA}}$ & $4.63 \pm 0.28^{\mathrm{bB}}$ & $5.27 \pm 0.17^{\mathrm{cA}}$ \\
\hline & \multirow{4}{*}{$\mathrm{PPS}^{4)}$} & 0.05 & $4.52 \pm 0.47^{\mathrm{dB}}$ & $4.33 \pm 0.33^{\mathrm{dB}}$ & $4.40 \pm 0.33^{\mathrm{eB}}$ & $4.18 \pm 0.43^{\mathrm{cB}}$ & $5.00 \pm 0.54^{\mathrm{cA}}$ \\
\hline & & 0.1 & $4.95 \pm 0.31^{\mathrm{bcAB}}$ & $4.90 \pm 0.31^{\mathrm{cAB}}$ & $5.02 \pm 0.37^{\mathrm{dA}}$ & $4.61 \pm 0.61^{\mathrm{bB}}$ & $5.05 \pm 0.24^{\mathrm{cA}}$ \\
\hline & & 0.15 & $5.44 \pm 0.19^{\mathrm{aA}}$ & $5.42 \pm 0.46^{\mathrm{bA}}$ & $5.60 \pm 0.31^{\mathrm{abA}}$ & $5.54 \pm 0.46^{\mathrm{aA}}$ & $5.62 \pm 0.46^{\mathrm{bA}}$ \\
\hline & & 0.2 & $5.39 \pm 0.55^{\mathrm{aB}}$ & $5.78 \pm 0.42^{\mathrm{aAB}}$ & $5.73 \pm 0.39^{\mathrm{aAB}}$ & $5.74 \pm 0.56^{\mathrm{aAB}}$ & $5.97 \pm 0.39^{\mathrm{aA}}$ \\
\hline
\end{tabular}

\footnotetext{
${ }^{1)}$ Mean \pm SD ( $\left.=8\right)$
}

${ }^{2)}$ Values with different superscript in a row (A-D) and column (a-e) are significant at $p<0.05$ by Duncan's multiple range test.

${ }^{3)}$ NPPS, Nanopowdered peanut sprout

${ }^{4)}$ PPS, Powdered peanut sprout 
Seo et al. (2009) also reported that the addition of nanopowdered chitosan in yogurt greatly increased the $b^{*}$ values during the increase storage period due to the light yellow color of the nanochitosan. However, $b^{*}$ values was found to be not significantly different at 0.05 and $0.10 \%$ of NPPS addition during the storage period from 0 to $16 \mathrm{~d}$ of storage $(p<0.05)$. Therefore, the results indicated that there were no considerable changes in color values of the NPPS- or PPS-added yogurt samples at various concentrations during the $16 \mathrm{~d}$ storage.

\section{Sensory evaluation}

The sensory properties of NPPS and PPS-added yogurt stored at $4^{\circ} \mathrm{C}$ for $16 \mathrm{~d}$ are shown in Tables 3 and 4. Appearance, flavor, taste, and texture properties were ana- lyzed with increasing concentrations $(0.05,0.10,0.15$, and $0.20 \%$ ) of NPPS and PPS addition at the storage period of $16 \mathrm{~d}$. The whey-off scores for the NPPS- or PPS-added yogurt at different concentrations and for the control were not significantly different at $0 \mathrm{~d}(p>0.05)$. However, during the extended storage period of $16 \mathrm{~d}$, the whey-off score increased with increase concentrations of NPPS or PPS addition to the yogurt. Similarly yellowness was found to be increased with the increase addition of NPPS and PPS to the yogurt irrespective of its storage time to $16 \mathrm{~d}$. Peanut and beany flavor significantly increased with increased addition of NPPS or PPS in yogurt at 0 to $16 \mathrm{~d}(p<0.05)$. Increase in the peanut and beany flavor most likely due to the increase oxidation of peanut fat during the storage period. However, at the lower con-

Table 3. Sensory characteristics of nanopowdered peanut sprout added-yogurt stored at $4^{\circ} \mathrm{C}$ for $16 \mathrm{~d}$

\begin{tabular}{|c|c|c|c|c|c|c|c|c|c|c|}
\hline \multirow{2}{*}{\multicolumn{2}{|c|}{$\begin{array}{l}\text { Concentrations } \\
(\%, w / v) \text { of } \\
\text { sample }\end{array}$}} & \multicolumn{2}{|c|}{ Appearance } & \multicolumn{2}{|c|}{ Flavor } & \multicolumn{2}{|c|}{ Taste } & \multicolumn{2}{|c|}{ Texture } & \multirow{2}{*}{$\begin{array}{c}\text { Overall } \\
\text { acceptabilty }\end{array}$} \\
\hline & & Whey-off & ellown & Peanut & Beany & Bitterness & Astri & Grainy & Weak & \\
\hline \multicolumn{11}{|c|}{0 d storage } \\
\hline \multirow{5}{*}{$\mathrm{NPPS}^{3)}$} & control & $1.00 \pm 0.00^{1) \mathrm{a} 2)}$ & $1.00 \pm 0.00^{\mathrm{d}}$ & $1.00 \pm 0.00^{\mathrm{c}}$ & $1.00 \pm 0.00^{\mathrm{d}}$ & $1.00 \pm 0.00^{\mathrm{a}}$ & $1.60 \pm 0.84^{\mathrm{b}}$ & $1.00 \pm 0.00^{\mathrm{c}}$ & $4.00 \pm 0.00^{\mathrm{b}}$ & $4.30 \pm 1.34^{\mathrm{bcd}}$ \\
\hline & 0.05 & $1.00 \pm 0.00^{\mathrm{a}}$ & $1.40 \pm 0.84^{\mathrm{cd}}$ & $1.40 \pm 0.52^{\mathrm{c}}$ & $1.60 \pm 0.52^{\mathrm{cd}}$ & $1.20 \pm 0.42^{\mathrm{a}}$ & $2.60 \pm 1.07^{\mathrm{ab}}$ & $1.20 \pm 0.42^{\mathrm{c}}$ & $4.20 \pm 0.42^{b}$ & $5.90 \pm 0.99^{\mathrm{a}}$ \\
\hline & 0.10 & $1.00 \pm 0.00^{\mathrm{a}}$ & $1.90 \pm 0.74^{\mathrm{abc}}$ & $3.30 \pm 0.82^{\mathrm{b}}$ & $2.40 \pm 0.84^{\mathrm{c}}$ & $1.30 \pm 0.48^{\mathrm{a}}$ & $2.70 \pm 0.95^{\mathrm{ab}}$ & $2.50 \pm 0.53^{b}$ & $5.60 \pm 0.70^{\mathrm{a}}$ & $4.90 \pm 0.74^{\mathrm{b}}$ \\
\hline & 0.15 & $1.00 \pm 0.00^{\mathrm{a}}$ & $1.80 \pm 0.79^{\mathrm{bc}}$ & $3.40 \pm 1.07^{\mathrm{ab}}$ & $2.50 \pm 0.71^{\mathrm{bc}}$ & $1.40 \pm 0.52^{\mathrm{a}}$ & $2.60 \pm 1.43^{\mathrm{ab}}$ & $3.00 \pm 1.05^{\mathrm{b}}$ & $5.80 \pm 0.42^{\mathrm{a}}$ & $3.80 \pm 0.92^{\mathrm{cd}}$ \\
\hline & 0.20 & $1.00 \pm 0.00^{\mathrm{a}}$ & $2.50 \pm 1.18^{\mathrm{ab}}$ & $4.20 \pm 1.32^{\mathrm{a}}$ & $4.00 \pm 1.41$ & $1.50 \pm 0.53^{\mathrm{a}}$ & $3.10 \pm 1.45^{\mathrm{a}}$ & $3.10 \pm 1.91^{\mathrm{b}}$ & $5.90 \pm 0.32^{\mathrm{a}}$ & $3.40 \pm 0.84^{\mathrm{cd}}$ \\
\hline \multicolumn{11}{|c|}{4 d storage } \\
\hline \multirow{5}{*}{ NPPS } & control & $1.00 \pm 0.00^{\mathrm{b}}$ & $1.00 \pm 0.00^{\mathrm{c}}$ & $1.00 \pm 0.00^{\mathrm{d}}$ & $1.00 \pm 0.00^{\mathrm{d}}$ & $1.20 \pm 0.42^{\mathrm{a}}$ & $1.90 \pm 0.99^{c}$ & $1.00 \pm 0.00^{\mathrm{d}}$ & $4.00 \pm 0.00^{\mathrm{b}}$ & $4.50 \pm 1.27^{\mathrm{abc}}$ \\
\hline & 0.05 & $1.00 \pm 0.00^{\mathrm{b}}$ & $1.50 \pm 0.53^{\mathrm{bc}}$ & $1.40 \pm 0.52^{\mathrm{cd}}$ & $2.60 \pm 0.97^{\mathrm{cB}}$ & $1.40 \pm 0.52^{\mathrm{a}}$ & $2.80 \pm 1.03^{\mathrm{abc}}$ & $1.40 \pm 0.52^{\mathrm{cd}}$ & $4.00 \pm 0.00^{\mathrm{b}}$ & $5.10 \pm 0.88^{\mathrm{a}}$ \\
\hline & 0.10 & $1.00 \pm 0.00^{\mathrm{b}}$ & $1.70 \pm 0.48^{\mathrm{b}}$ & $2.30 \pm 1.16^{\mathrm{bc}}$ & $2.70 \pm 1.42^{\mathrm{c}}$ & $1.50 \pm 0.71^{\mathrm{a}}$ & $2.90 \pm 0.57^{\mathrm{ab}}$ & $2.30 \pm 0.48^{\mathrm{bc}}$ & $4.40 \pm 0.52^{\mathrm{ab}}$ & $4.60 \pm 0.97^{\mathrm{ab} A \mathrm{~B}}$ \\
\hline & 0.15 & $1.00 \pm 0.00^{\mathrm{b}}$ & $1.90 \pm 0.74^{\mathrm{ab}}$ & $3.20 \pm 1.55^{\mathrm{ab}}$ & $3.60 \pm 1.43^{\mathrm{abc}}$ & $1.60 \pm 0.97^{\mathrm{a}}$ & $3.70 \pm 1.25^{\mathrm{a}}$ & $2.20 \pm 1.14^{\mathrm{bc}}$ & $4.50 \pm 0.97^{\mathrm{ab}}$ & $4.20 \pm 0.63^{\mathrm{abc}}$ \\
\hline & 0.20 & $1.00 \pm 0.00^{\mathrm{b}}$ & $2.10 \pm 0.57^{\mathrm{ab}}$ & $4.00 \pm 1.83^{\mathrm{a}}$ & $3.70 \pm 1.49^{\mathrm{abc}}$ & $1.60 \pm 0.84^{\mathrm{a}}$ & $2.90 \pm 0.99^{\mathrm{ab}}$ & $2.80 \pm 1.62^{\mathrm{ab}}$ & $4.90 \pm 0.99^{\mathrm{a}}$ & $3.70 \pm 0.67^{\mathrm{bc}}$ \\
\hline \multicolumn{11}{|c|}{$8 \mathrm{~d}$ storage } \\
\hline \multirow{5}{*}{ NPPS } & control & $1.00 \pm 0.00^{\mathrm{b}}$ & $1.00 \pm 0.00^{\mathrm{d}}$ & $1.00 \pm 0.00^{\mathrm{d}}$ & $1.00 \pm 0.00^{\mathrm{c}}$ & $1.30 \pm 0.48^{\mathrm{a}}$ & $1.80 \pm 0.92^{\mathrm{b}}$ & $1.00 \pm 0.00^{\mathrm{d}}$ & $3.80 \pm 0.42^{\mathrm{b}}$ & $4.50 \pm 0.97^{\mathrm{abc}}$ \\
\hline & 0.05 & $1.00 \pm 0.00^{\mathrm{b}}$ & $1.10 \pm 0.32^{\mathrm{cd}}$ & $2.60 \pm 0.84^{\mathrm{c}}$ & $3.20 \pm 1.32^{\mathrm{ab}}$ & $1.80 \pm 0.63^{\mathrm{a}}$ & $2.90 \pm 1.37^{\mathrm{a}}$ & $1.50 \pm 0.53^{\mathrm{cd}}$ & $4.10 \pm 0.74^{\mathrm{b}}$ & $4.90 \pm 1.20^{\mathrm{a}}$ \\
\hline & 0.10 & $1.00 \pm 0.00^{\mathrm{b}}$ & $1.90 \pm 0.74^{\mathrm{abc}}$ & $2.50 \pm 1.08^{\mathrm{c}}$ & $2.90 \pm 1.20^{\mathrm{b}}$ & $1.80 \pm 0.92^{\mathrm{a}}$ & $2.80 \pm 1.03^{\mathrm{ab}}$ & $2.10 \pm 0.57^{\mathrm{c}}$ & $5.20 \pm 0.63^{\mathrm{a}}$ & $4.20 \pm 0.92^{\mathrm{abcd}}$ \\
\hline & 0.15 & $1.00 \pm 0.00^{\mathrm{b}}$ & $1.90 \pm 0.57^{\mathrm{abc}}$ & $3.60 \pm 1.58^{\mathrm{ac}}$ & $3.80 \pm 1.75^{\mathrm{ab}}$ & $1.80 \pm 0.79^{\mathrm{a}}$ & $3.10 \pm 1.20^{\mathrm{a}}$ & $2.90 \pm 1.10^{\mathrm{b}}$ & $5.30 \pm 0.67^{\mathrm{a}}$ & $3.60 \pm 1.26^{\mathrm{bcd}}$ \\
\hline & 0.20 & $1.00 \pm 0.00^{\mathrm{b}}$ & $2.40 \pm 0.84^{\mathrm{a}}$ & $3.80 \pm 1.48^{\mathrm{a}}$ & $3.60 \pm 1.17^{\mathrm{ab}}$ & $2.00 \pm 0.67^{\mathrm{a}}$ & $3.20 \pm 0.79^{\mathrm{a}}$ & $3.20 \pm 1.48^{\mathrm{b}}$ & $5.30 \pm 1.16^{\mathrm{a}}$ & $3.40 \pm 0.70^{\mathrm{cd}}$ \\
\hline \multicolumn{11}{|c|}{$12 \mathrm{~d}$ storage } \\
\hline \multirow{5}{*}{ NPPS } & control & $2.00 \pm 0.00^{\mathrm{b}}$ & $1.00 \pm 0.00^{\mathrm{d}}$ & $1.00 \pm 0.00^{\mathrm{d}}$ & $1.00 \pm 0.00^{\mathrm{c}}$ & $1.40 \pm 0.70^{\mathrm{a}}$ & $1.50 \pm 0.71^{\mathrm{c}}$ & $1.00 \pm 0.00^{\mathrm{e}}$ & $3.70 \pm 0.48^{\mathrm{b}}$ & $4.30 \pm 1.16^{\mathrm{ab}}$ \\
\hline & 0.05 & $2.00 \pm 0.00^{\mathrm{b}}$ & $1.20 \pm 0.42^{\mathrm{cd}}$ & $2.50 \pm 1.43^{\mathrm{c}}$ & $4.20 \pm 1.75^{\mathrm{ab}}$ & $1.70 \pm 0.82^{\mathrm{a}}$ & $3.00 \pm 0.82^{\mathrm{a}}$ & $1.50 \pm 0.53^{\mathrm{de}}$ & $4.20 \pm 0.79^{\mathrm{ab}}$ & $4.60 \pm 1.35^{\mathrm{a}}$ \\
\hline & 0.10 & $2.00 \pm 0.00^{\mathrm{b}}$ & $1.70 \pm 0.67^{\mathrm{bcd}}$ & $2.80 \pm 1.48^{\mathrm{bc}}$ & $3.00 \pm 1.33^{\mathrm{b}}$ & $1.50 \pm 0.71^{\mathrm{a}}$ & $2.90 \pm 1.10^{\mathrm{b}}$ & $2.20 \pm 0.79^{\mathrm{cd}}$ & $4.30 \pm 1.34^{\mathrm{ab}}$ & $3.90 \pm 0.74^{\mathrm{ab}}$ \\
\hline & 0.15 & $2.00 \pm 0.00^{\mathrm{b}}$ & $1.80 \pm 0.63^{\mathrm{bc}}$ & $4.20 \pm 1.75^{\mathrm{ab}}$ & $4.00 \pm 1.83^{\mathrm{ab}}$ & $1.70 \pm 0.67^{\mathrm{a}}$ & $3.50 \pm 0.85^{\mathrm{a}}$ & $3.10 \pm 1.60^{\mathrm{abc}}$ & $4.60 \pm 1.07^{\mathrm{a}}$ & $3.50 \pm 1.65^{\mathrm{ab}}$ \\
\hline & 0.20 & $2.00 \pm 0.00^{\mathrm{b}}$ & $2.30 \pm 0.95^{\mathrm{ab}}$ & $4.50 \pm 1.51^{\mathrm{a}}$ & $3.50 \pm 1.08^{\mathrm{ab}}$ & $1.30 \pm 0.48^{\mathrm{a}}$ & $3.40 \pm 0.97^{\mathrm{a}}$ & $3.40 \pm 1.17^{\mathrm{a}}$ & $4.70 \pm 0.82^{\mathrm{a}}$ & $3.50 \pm 1.08^{\mathrm{ab}}$ \\
\hline \multicolumn{11}{|c|}{$16 \mathrm{~d}$ storage } \\
\hline \multirow{5}{*}{ NPPS } & control & $3.00 \pm 0.00^{\mathrm{b}}$ & $1.00 \pm 0.00^{\mathrm{d}}$ & $1.00 \pm 0.00^{\mathrm{d}}$ & $1.00 \pm 0.00^{\mathrm{d}}$ & $1.20 \pm 0.63^{\mathrm{c}}$ & $1.90 \pm 0.88^{\mathrm{c}}$ & $1.00 \pm 0.00^{\mathrm{c}}$ & $3.70 \pm 0.48^{\mathrm{c}}$ & $4.40 \pm 1.07^{\mathrm{a}}$ \\
\hline & 0.05 & $3.00 \pm 0.00^{\mathrm{b}}$ & $1.60 \pm 0.52^{\mathrm{cd}}$ & $2.60 \pm 1.17^{\mathrm{c}}$ & $2.70 \pm 1.42^{\mathrm{bc}}$ & $1.20 \pm 0.42^{\mathrm{c}}$ & $2.30 \pm 0.95^{\mathrm{bc}}$ & $1.70 \pm 0.95^{\mathrm{c}}$ & $4.10 \pm 0.74^{\mathrm{ac}}$ & $4.30 \pm 0.82^{\mathrm{a}}$ \\
\hline & 0.10 & $3.00 \pm 0.00^{\mathrm{b}}$ & $2.00 \pm 0.82^{\mathrm{abc}}$ & $2.90 \pm 0.88^{\mathrm{bc}}$ & $2.50 \pm 0.97^{\mathrm{c}}$ & $1.20 \pm 0.42^{\mathrm{c}}$ & $2.60 \pm 0.70^{\mathrm{ac}}$ & $2.60 \pm 0.84^{b}$ & $4.70 \pm 0.95^{\mathrm{a}}$ & $4.00 \pm 0.67^{\mathrm{a}}$ \\
\hline & 0.15 & $3.00 \pm 0.00^{\mathrm{b}}$ & $2.30 \pm 0.95^{\mathrm{abc}}$ & $4.10 \pm 1.73^{\mathrm{ab}}$ & $3.20 \pm 1.14^{\mathrm{abc}}$ & $1.30 \pm 0.67^{\mathrm{bc}}$ & $2.60 \pm 0.84^{\mathrm{ac}}$ & $3.00 \pm 0.94^{\mathrm{ab}}$ & $4.70 \pm 0.48^{\mathrm{a}}$ & $4.20 \pm 1.03^{\mathrm{a}}$ \\
\hline & 0.20 & $3.00 \pm 0.00^{\mathrm{b}}$ & $2.50 \pm 1.27^{\mathrm{ab}}$ & $5.10 \pm 1.52^{\mathrm{a}}$ & $2.90 \pm 1.52^{\mathrm{bc}}$ & $1.50 \pm 0.85^{\mathrm{a}}$ & $2.80 \pm 0.63^{\mathrm{ab}}$ & $3.40 \pm 0.84^{\mathrm{ab}}$ & $4.70 \pm 0.82^{\mathrm{a}}$ & $3.60 \pm 0.84^{\mathrm{a}}$ \\
\hline
\end{tabular}

${ }^{1)}$ Mean \pm SD ( $\left.=8\right)$

${ }^{2)}$ Values with different superscript in a column (a-e) are significantly different at $p<0.05$ by Duncan's multiple range test.

${ }^{3)}$ NPPS, Nanopowdered peanut sprout 
centrations (0.05 and 0.10) of PPS or NPPS addition to the yogurt, peanut and beany flavor were lower during the storage. In the taste test, bitterness was found to be not significantly different during 0 to $16 \mathrm{~d}$ storage, irrespective of NPPS or PPS addition to the yogurt $(p<0.05)$. However, increasing the storage period of $16 \mathrm{~d}$ greatly increased the astringent score irrespective of the concentrations of NPPS or PPS addition to the yogurt. Seo et al. (2010) were also reported that addition of nanochitosan in yogurt greatly increased the astringent score in yogurt during the storage periods. In the texture test, grainy and weakness score increased with increase concentrations of NPPS or PPS addition to yogurt. However, at the lower concentrations of NPPS or PPS addition to the yogurt, grainy and weakness score were not much affected during the increase storage period of $16 \mathrm{~d}$. Similarly yam supplemented yogurt was also not affected the grainy and weakness score during the storage period of $16 \mathrm{~d}$ (Kim et al., 2011). In overall acceptability, lower concentrations $(0.05$ and $0.10 \%$ ) of NPPS or PPS addition has higher likeness score during the extended storage of $16 \mathrm{~d}$. Based on all the sensory data obtained from the current study, it is suggested that NPPS concentrations $(0.05$ and $0.10 \%)$ could be used for the addition to the yogurt without affecting the sensory properties.

In conclusions, NPPS addition markedly increased the yogurt quality than the PPS with the higher radical scavenging activity. Further nanogrinding increased the greater exposure of its functional site and surface area of peanut sprout which also enhance the growth of LAB in the NPPS-

Table 4. Sensory characteristics of powdered peanut sprout added-yogurt stored at $4^{\circ} \mathrm{C}$ for $16 \mathrm{~d}$

\begin{tabular}{|c|c|c|c|c|c|c|c|c|c|c|}
\hline \multirow{2}{*}{\multicolumn{2}{|c|}{$\begin{array}{c}\text { Concentra- } \\
\text { tions }(\%, w / v) \\
\text { of sample }\end{array}$}} & \multicolumn{2}{|c|}{ Appearance } & \multicolumn{2}{|c|}{ Flavor } & \multicolumn{2}{|c|}{ Taste } & \multicolumn{2}{|c|}{ Texture } & \multirow{2}{*}{$\begin{array}{c}\text { Overall } \\
\text { acceptabilty }\end{array}$} \\
\hline & & Whey-off & Yellc & Peanut & Beany & ness & $y$ & Grainy & Weak & \\
\hline \multicolumn{11}{|c|}{0 d storage } \\
\hline \multirow{5}{*}{ PPS $^{3)}$} & control & $1.00 \pm 0.00^{1) \mathrm{a} 2)}$ & $1.00 \pm 0.00^{\mathrm{d}}$ & $1.00 \pm 0.00^{\mathrm{c}}$ & $1.00 \pm 0.00^{\mathrm{d}}$ & $1.00 \pm 0.00^{\mathrm{a}}$ & $1.60 \pm 0.84^{\mathrm{b}}$ & $1.00 \pm 0.00^{\mathrm{c}}$ & $4.00 \pm 0.00^{\mathrm{b}}$ & $4.30 \pm 1.34^{\mathrm{bcd}}$ \\
\hline & 0.05 & $1.00 \pm 0.00^{\mathrm{a}}$ & $1.50 \pm 0.53^{\mathrm{cd}}$ & $3.10 \pm 0.88^{\mathrm{b}}$ & $2.70 \pm 1.42^{\mathrm{bc}}$ & $1.60 \pm 1.07^{\mathrm{a}}$ & $1.80 \pm 0.92^{\mathrm{b}}$ & $1.60 \pm 0.97^{\mathrm{c}}$ & $4.10 \pm 0.57^{b}$ & $5.20 \pm 0.79^{\mathrm{ab}}$ \\
\hline & 0.10 & $1.00 \pm 0.00^{\mathrm{a}}$ & $2.00 \pm 0.47^{\mathrm{abc}}$ & $3.10 \pm 0.74^{\mathrm{b}}$ & $3.60 \pm 1.26^{\mathrm{ab}}$ & $1.50 \pm 0.85^{\mathrm{a}}$ & $2.00 \pm 0.94^{\mathrm{ab}}$ & $3.40 \pm 0.70^{\mathrm{ab}}$ & $4.10 \pm 0.32^{\mathrm{b}}$ & $4.40 \pm 0.52^{b c}$ \\
\hline & 0.15 & $1.00 \pm 0.00^{\mathrm{a}}$ & $2.00 \pm 0.67^{\mathrm{abc}}$ & $3.40 \pm 0.84^{\mathrm{ab}}$ & $4.50 \pm 1.96^{\mathrm{a}}$ & $1.50 \pm 0.85^{\mathrm{a}}$ & $2.20 \pm 1.32^{\mathrm{ab}}$ & $3.20 \pm 1.14^{\mathrm{b}}$ & $4.20 \pm 0.79^{b}$ & $3.60 \pm 1.51^{\mathrm{cd}}$ \\
\hline & 0.20 & $1.00 \pm 0.00^{\mathrm{a}}$ & & $4.20 \pm 1.14^{\mathrm{a}}$ & $4.70 \pm 1.70^{\mathrm{a}}$ & $08^{\mathrm{a}}$ & & $4.20 \pm 0.92^{\mathrm{a}}$ & $4.40 \pm$ & $3.30 \pm 1.16^{\mathrm{d}}$ \\
\hline \multicolumn{11}{|c|}{$4 \mathrm{~d}$ storage } \\
\hline \multirow{5}{*}{ PPS } & control & $1.00 \pm 0.00^{\mathrm{b}}$ & $1.00 \pm 0.00^{\mathrm{c}}$ & $1.00 \pm 0.00^{\mathrm{d}}$ & $1.00 \pm 0.00^{\mathrm{d}}$ & $1.20 \pm 0.42^{\mathrm{a}}$ & $1.90 \pm 0.99^{c}$ & $1.00 \pm 0.00^{\mathrm{d}}$ & $4.00 \pm 0.00^{\mathrm{b}}$ & $4.50 \pm 1.27^{\mathrm{ab}}$ \\
\hline & 0.05 & $1.00 \pm 0.00^{\mathrm{b}}$ & $1.50 \pm 0.71^{\mathrm{c}}$ & $3.70 \pm 1.16^{\mathrm{a}}$ & $3.00 \pm 1.15^{\mathrm{abc}}$ & $1.60 \pm 0.84^{\mathrm{a}}$ & $2.70 \pm 0.67^{\mathrm{bc}}$ & $2.20 \pm 1.14^{\mathrm{bc}}$ & $3.90 \pm 0.32^{\mathrm{b}}$ & $4.90 \pm 0.88^{\mathrm{a}}$ \\
\hline & 0.10 & $2.00 \pm 0.00^{\mathrm{a}}$ & $1.90 \pm 0$ & $3.20 \pm 0.92^{\mathrm{ab}}$ & $2.90 \pm 1.20^{\mathrm{bc}}$ & $1.70 \pm 1.06^{\mathrm{a}}$ & $2.40 \pm 0.84^{\mathrm{bc}}$ & $2.40 \pm 1.17^{\mathrm{b}}$ & $4.10 \pm 0.57^{b}$ & $4.30 \pm 0.82^{\mathrm{abc}}$ \\
\hline & 0.15 & $2.00 \pm 0.00^{\mathrm{a}}$ & $1.90 \pm 0.74^{\mathrm{ab}}$ & $4.10 \pm 1.37^{\mathrm{a}}$ & $4.00 \pm 1.41^{\mathrm{ab}}$ & $1.60 \pm 0.84^{\mathrm{a}}$ & $2.90 \pm 0.99^{\mathrm{ab}}$ & $3.40 \pm 1.07^{\mathrm{a}}$ & $4.30 \pm 0.82^{\mathrm{ab}}$ & $3.70 \pm 1.16^{\mathrm{bc}}$ \\
\hline & 0.20 & $2.00 \pm 0.00^{\mathrm{a}}$ & $2.40 \pm 1.07^{\mathrm{a}}$ & $4.10 \pm$ & $4.20 \pm 1.40^{\mathrm{a}}$ & $1.60 \pm 0.97^{\mathrm{a}}$ & $2.90 \pm 0.88^{\mathrm{ab}}$ & $3.70 \pm 0.82^{\mathrm{a}}$ & $4.50 \pm$ & $3.60 \pm 0.70^{\mathrm{c}}$ \\
\hline \multicolumn{11}{|c|}{$8 \mathrm{~d}$ storage } \\
\hline \multirow{5}{*}{ PPS } & control & $1.00 \pm 0.00^{\mathrm{b}}$ & $1.00 \pm 0.00^{\mathrm{d}}$ & $1.00 \pm 0.00^{\mathrm{d}}$ & $1.00 \pm 0.00^{\mathrm{c}}$ & $1.30 \pm 0.48^{\mathrm{a}}$ & $1.80 \pm 0.92^{\mathrm{b}}$ & $1.00 \pm 0.00^{\mathrm{d}}$ & $3.80 \pm 0.42^{\mathrm{b}}$ & $4.50 \pm 0.97^{\mathrm{abc}}$ \\
\hline & 0.05 & $1.00 \pm 0.00^{\mathrm{b}}$ & $1.50 \pm 0.53^{\mathrm{bcd}}$ & $3.60 \pm 1.07^{\mathrm{ac}}$ & $3.50 \pm 1.65^{\mathrm{ab}}$ & $1.90 \pm 1.37^{\mathrm{a}}$ & $2.80 \pm 0.79^{\mathrm{ab}}$ & $1.90 \pm 0.88^{\mathrm{c}}$ & $4.10 \pm 0.57^{b}$ & $4.60 \pm 1.35^{\mathrm{ab}}$ \\
\hline & 0.10 & $2.00 \pm 0.00^{\mathrm{a}}$ & $1.90 \pm 0.88^{\mathrm{abc}}$ & $2.70 \pm 1.16^{\mathrm{c}}$ & $2.60 \pm 1.35^{\mathrm{b}}$ & $1.80 \pm 1.14^{\mathrm{a}}$ & $2.70 \pm 0.95^{\mathrm{ab}}$ & $2.00 \pm 0.82^{\mathrm{c}}$ & $4.10 \pm 0.32^{b}$ & $4.00 \pm 1.25^{\mathrm{abcd}}$ \\
\hline & 0.15 & $2.00 \pm 0.00^{\mathrm{a}}$ & $2.30 \pm 1.16^{\mathrm{ab}}$ & $4.10 \pm 1.79^{\mathrm{a}}$ & $4.60 \pm 1.78^{\mathrm{a}}$ & $1.80 \pm 1.14^{\mathrm{a}}$ & $2.60 \pm 0.70^{\mathrm{ab}}$ & $3.60 \pm 0.84^{\mathrm{ab}}$ & $4.10 \pm 0.99^{b}$ & $3.30 \pm 1.06^{\mathrm{d}}$ \\
\hline & 0.20 & $2.00 \pm 0.00^{\mathrm{a}}$ & $2.60 \pm 1.58^{\mathrm{a}}$ & $4.00 \pm 1.63^{\mathrm{a}}$ & $3.70 \pm 1.57^{\mathrm{ab}}$ & $1.90 \pm 1.10^{\mathrm{a}}$ & $3.30 \pm 1.16^{\mathrm{a}}$ & $4.30 \pm 1.06^{\mathrm{a}}$ & $4.20 \pm 1.14^{\mathrm{b}}$ & $3.40 \pm 0.97^{\mathrm{cd}}$ \\
\hline \multicolumn{11}{|c|}{$12 \mathrm{~d}$ storage } \\
\hline \multirow{5}{*}{ PPS } & control & $2.00 \pm 0.00^{\mathrm{b}}$ & $1.00 \pm 0.00^{\mathrm{d}}$ & $1.00 \pm 0.00^{\mathrm{d}}$ & $1.00 \pm 0.00^{\mathrm{c}}$ & $1.40 \pm 0.70^{\mathrm{a}}$ & $1.50 \pm 0.71^{\mathrm{c}}$ & $1.00 \pm 0.00^{\mathrm{e}}$ & $3.70 \pm 0.48^{b}$ & $4.30 \pm 1.16^{\mathrm{ab}}$ \\
\hline & 0.05 & $2.00 \pm 0.00^{\mathrm{b}}$ & $1.80 \pm 0.79^{\mathrm{bc}}$ & $3.60 \pm 1.26^{\mathrm{abc}}$ & $3.70 \pm 1.42^{\mathrm{ab}}$ & $1.90 \pm 0.99^{\mathrm{a}}$ & $2.30 \pm 1.16^{\mathrm{a}}$ & $1.60 \pm 0.70^{\mathrm{de}}$ & $4.00 \pm 0.67^{\mathrm{ab}}$ & $4.00 \pm 1.63^{\mathrm{ab}}$ \\
\hline & 0.10 & $3.00 \pm 0.00^{\mathrm{a}}$ & $2.20 \pm 0.63^{\mathrm{ab}}$ & $3.10 \pm 1.20^{\mathrm{abc}}$ & $3.20 \pm 1.48^{\mathrm{ab}}$ & $1.60 \pm 0.97^{\mathrm{a}}$ & $2.40 \pm 1.07^{\mathrm{a}}$ & $2.40 \pm 0.97^{\mathrm{bcd}}$ & $4.20 \pm 0.42^{\mathrm{ab}}$ & $3.70 \pm 1.34^{\mathrm{ab}}$ \\
\hline & 0.15 & $3.00 \pm 0.00^{\mathrm{a}}$ & $2.40 \pm 1.17^{\mathrm{ab}}$ & $4.00 \pm 1.63^{\mathrm{ab}}$ & $4.60 \pm 1.65^{\mathrm{a}}$ & $2.10 \pm 1.10^{\mathrm{a}}$ & $2.70 \pm 1.16^{\mathrm{a}}$ & $3.30 \pm 0.82^{\mathrm{ab}}$ & $4.40 \pm 0.97^{\mathrm{ab}}$ & $3.10 \pm 1.79^{\mathrm{b}}$ \\
\hline & 0.20 & $3.00 \pm 0.00^{\mathrm{a}}$ & $2.70 \pm 1.06^{\mathrm{a}}$ & $3.90 \pm 1.52^{\mathrm{ab}}$ & $4.00 \pm 1.25^{\mathrm{ab}}$ & $1.80 \pm 1.23^{\mathrm{a}}$ & $2.90 \pm 0.88^{\mathrm{a}}$ & $3.70 \pm 1.57^{\mathrm{a}}$ & $4.40 \pm 0.84^{\mathrm{ab}}$ & $2.90 \pm 1.37^{\mathrm{b}}$ \\
\hline \multicolumn{11}{|c|}{$16 \mathrm{~d}$ storage } \\
\hline \multirow{5}{*}{ PPS } & control & $3.00 \pm 0.00^{\mathrm{b}}$ & $1.00 \pm 0.00^{\mathrm{d}}$ & $1.00 \pm 0.00^{\mathrm{d}}$ & $1.00 \pm 0.00^{\mathrm{d}}$ & $1.20 \pm 0.63^{\mathrm{c}}$ & $1.90 \pm 0.88^{\mathrm{c}}$ & $1.00 \pm 0.00^{\mathrm{c}}$ & $3.70 \pm 0.48^{\mathrm{c}}$ & $4.40 \pm 1.07^{\mathrm{a}}$ \\
\hline & 0.05 & $3.00 \pm 0.00^{\mathrm{b}}$ & $1.60 \pm 0.52^{\mathrm{cd}}$ & $3.70 \pm 1.42^{\mathrm{bc}}$ & $3.80 \pm 1.40^{\mathrm{ab}}$ & $2.00 \pm 0.94^{\mathrm{ab}}$ & $3.30 \pm 1.42^{\mathrm{ab}}$ & $1.80 \pm 0.79^{\mathrm{c}}$ & $4.00 \pm 0.00^{\mathrm{bc}}$ & $3.90 \pm 1.52^{\mathrm{a}}$ \\
\hline & 0.10 & $4.00 \pm 0.00^{\mathrm{a}}$ & $1.70 \pm 0.67^{\mathrm{bcd}}$ & $3.10 \pm 1.45^{\mathrm{bc}}$ & $2.90 \pm 0.99^{\mathrm{bc}}$ & $1.90 \pm 0.74^{\mathrm{ac}}$ & $2.90 \pm 1.29^{\mathrm{ac}}$ & $2.70 \pm 0.67^{\mathrm{a}}$ & $4.00 \pm 0.47^{\mathrm{bc}}$ & $3.80 \pm 1.14^{\mathrm{a}}$ \\
\hline & 0.15 & $4.00 \pm 0.00^{\mathrm{a}}$ & $2.10 \pm 0.88^{\mathrm{abc}}$ & $4.20 \pm 1.48^{\mathrm{ab}}$ & $4.30 \pm 1.34^{\mathrm{a}}$ & $2.10 \pm 0.88^{\mathrm{a}}$ & $3.40 \pm 1.26^{\mathrm{a}}$ & $3.00 \pm 1.33^{\mathrm{ab}}$ & $4.40 \pm 0.52^{\mathrm{ab}}$ & $3.50 \pm 0.97^{\mathrm{a}}$ \\
\hline & 0.20 & $4.00 \pm 0.00^{\mathrm{a}}$ & $2.60 \pm 1.07^{\mathrm{a}}$ & $4.20 \pm 1.62^{\mathrm{ab}}$ & $3.80 \pm 1.40^{\mathrm{a}}$ & $1.80 \pm 0.79^{\mathrm{ac}}$ & $3.10 \pm 1.10^{\mathrm{a}}$ & $3.50 \pm 0.97^{\mathrm{a}}$ & $4.50 \pm 0.71^{\mathrm{ab}}$ & $3.40 \pm 0.84^{\mathrm{a}}$ \\
\hline
\end{tabular}

${ }^{1)}$ Mean \pm SD (n=8)

${ }^{2)}$ Values with different superscript in a column (a-e) are significantly different at $p<0.05$ by Duncan's multiple range test.

${ }^{3)}$ PPS, Powdered peanut sprout 
than in PPS-added yogurt. In addition, the data on $\mathrm{pH}$, viscosity, $\mathrm{LAB}, \mathrm{DPPH}$, color, and sensory analysis indicated that the lower concentrations $(0.05$ and $0.10 \%)$ of NPPS could be applicable in the development of functional yogurt with higher antiradical scavenging activity. The production of the yogurt which incorporates the NPPS can broaden the utilization of nanopeanut sprout and the products can be regarded as possible health-promoting nutraceutical foods.

\section{Acknowledgements}

This study was supported by a grant from Small and Medium Business Administration in Seoul, Republic of Korea.

\section{References}

1. Abodjo Kakou, C., Tagro Guehi, S., Olo, K., Akissi Kouame, F., Koffi Nevry, R., and Marina Koussemon, C. (2010) Biochemical and microbial changes during traditional spontaneous lactic acid fermentation process using two varieties of cassava for production of a "Alladjan" starter. Int. Food Res. J. 17, 563-573.

2. Brand-Williams, W., Cuvelier, M. E., and Berset, C. (1995) Use of a free radical method to evaluate antioxidant activity. Lebensm- Wissu- Technol. 28, 25-30.

3. Gobbetti, M., Minervini, F., and Rizzello, C. G. (2004) Angiotensin I-converting-enzyme-inhibitory and antimicrobial bioactive peptide Int. J. Dairy Technol. 57, 172-188.

4. Isleten, M. and Karagul Yuceer, Y. (2006) Effects of dried dairy ingredients on physical and sensory properties of nonfat yogurt. J. Dairy Sci. 89, 2865-2872.

5. Kang, H. I., Kim, J. Y., Park, K. W., Kang, J. S., Choi, M. R., Moon, K. D., and Seo, K. I. (2010) Antioxidative effect of peanut sprout extracts. Korean J. Food Sci. Nutr. 39, 941946.

6. Kim, S. H., Lee, S. Y., Palanivel, G., and Kwak, H. S. (2011) Effect of Dioscorea opposita Thunb. (yam) supplementation on physicochemical and sensory characteristics of yogurt $J$. Dairy Sci. 94, 1705-1712.
7. Park, H. S., Jeon, B. J., Ahn, J., and Kwak, H. S. (2007) Effects of nanocalcium supplemented milk on bone calcium metabolism in ovariectomized rats. Asian-Aust. J. Anim. Sci. 20, 1266-1271.

8. Sahan, N., Yasar, K, and Hayaloglu, A. A. (2008) Physical, chemical and flavor quality of non-fat yogurt as affected by a $\beta$-glucan hydrocolloidal composite during storage. Food Hydrocoll. 22, 1291-1297.

9. SAS Institute, (2002) SAS User's Guide: Statistics, Version 9.0 Cary, NC.

10. Seo, M. H, Lee, S. Y., Chang, Y. H., and Kwak, H. S. (2009) Physicochemical, microbial, and sensory properties of yogurt supplemented with nanopowdered chitosan during storage. J. Dairy Sci. 92, 5907-5916.

11. Seo, M. H, Chang, Y. H., Lee, S., and Kwak, H. S. (2011) The Physicochemical and sensory properties of milk supplemented with ascorbic acid-soluble nano chitosan during storage. Inter J. Dairy Technol. 64, 57-63.

12. Servili, M., Esposto, S., Fabiani, R., Urbani, S., Taticchi, A., Mariucci, F., Selvaggini, R., and Montedoro, G. F. (2009) Phenolic compounds in olive oil: antioxidant, health and sensory activities according to their chemical structure. Inflammopharmacology 17, 1-9.

13. Sharma, S., Anjaneyulu, M., Kulkarni, S. K., and Chopra, K. (2006) Resveratrol, a polyphenolic phytoalexin, attenuates diabetic nephropathy in rats. Pharmacology 76, 69-75.

14. Shirai, K., Pedraza, G., Gutierrez-Durán, M., Marshall, V. M. E., Revah-Moiseev, S., and García-Garibay, M. (1992) Production of a yogurt-like product from plant foodstuffs and whey. Substrate preparation and fermentation. J. Sci. Food Agric. 59, 199-204.

15. Vijayendra, S. V. N., Palanivel, G., Mahadevamma, S., Tharanathan, R. N. (2008) Physico-chemical characterization of an exopolysaccharide produced by a non-ropy strain of $\mathrm{Leu}$ conostoc sp. CFR 2181 isolated from dahi, an Indian traditional lactic fermented milk product. Carbohyd. Polym. 72, 300-307.

16. Wang, Y., Catana, F., Yang, Y., Roderick, R., and van Breemen R. B. (2002) An LC-MS method for analyzing total resveratrol in grape juice, cranberry juice, and in wine. J. Agric. Food Chem. 50, 431-435.

(Received 2012.6.26/Revised 2012.8.28/Accepted 2012.9.1) 